\title{
Infections identified by serological screening at blood donors in Dolj County
}

\author{
Livia Dragonu ${ }^{1,2^{*}}$, Dan Hurezeanu ${ }^{1,2}$, Sevastiana Bran ${ }^{3}$, Irina Niculescu ${ }^{1,2}$, Daniela Ristea ${ }^{2}$, Magdalena Peter ${ }^{2}$, \\ Carmen Canciovici ${ }^{2}$, Doina Ene ${ }^{2}$, Maria Bălan ${ }^{2}$, Mădălina Sandu² \\ From The 10th Edition of the Scientific Days of the National Institute for Infectious Diseases "Prof Dr Matei Bals" \\ Bucharest, Romania. 15-17 October 2014
}

\section{Background}

Serological screening of blood donors provides data on seroprevalence of certain infections among apparently healthy people of working age population belonging to a particular geographic area. The study's objectives pursued the prevalence of infection with hepatitis B (HBV), hepatitis $\mathrm{C}$ virus (HCV), human immunodeficiency virus (HIV) and Treponema pallidum on a sample population of Dolj County represented by volunteer blood donors.

\section{Methods}

The retrospective study included results from the immunological tests performed at the Regional Centre for Transfusion and Blood Conservation Craiova during the $1^{\text {st }}$ of January 2008 and the $31^{\text {st }}$ of December 2013. The testing included 28,091 adults with ages ranging between 20 and 64 years with no risk factors that met the criteria of selection for blood donation. The immunology test was performed by ELISA to determine HBsAg, HCV-Ab, antiHIV and anti-Treponema pallidum IgG.

\section{Results}

Infections without clinical manifestation have been identified in $5.92 \%$ of blood donors tested: HBsAg - 3.53\%, Treponema pallidum - $1.55 \%$, HCV-Ab - 0.8\%, anti-HIV $0.02 \%$. During the studied interval, there was a decrease in the cases detected in the year 2013 (6.1\% vs. 5\%). The distribution by gender revealed statistically significant differences for male HBV infections (4.5\% vs. $2.1 \%)$ and for females in HCV infection (1.09\% vs. $0.62 \%)$. In relation to age, higher prevalence in young patients (20-35 years) was found for HIV and HBV and after 35 years infection with HCV and Treponema pallidum.

\footnotetext{
* Correspondence: livia_dragonu@yahoo.com

'University of Medicine and Pharmacy Craiova, Romania

Full list of author information is available at the end of the article
}

\section{Conclusion}

The prevalence of infections with $\mathrm{HBV}, \mathrm{HCV}, \mathrm{HIV}$ and Treponema pallidum did not exceed the average values for the studied population. The risk of infection of the blood test showed etiological features related to age and sex. Health education measures and specific prophylaxis may limit the transmission of these infections within the community.

\section{Authors' details}

"University of Medicine and Pharmacy Craiova, Romania. "Victor Babeş" Clinical Hospital of Infectious Diseases and Pneumology, Craiova, Romania. ${ }^{3}$ Regional Centre for Transfusion and Blood Conservation Craiova, Romania.

Published: 15 October 2014

\section{doi:10.1186/1471-2334-14-S7-P38}

Cite this article as: Dragonu et al:: Infections identified by serological screening at blood donors in Dolj County. BMC Infectious Diseases 2014 14(Suppl 7):P38.

\section{Submit your next manuscript to BioMed Central and take full advantage of: \\ - Convenient online submission \\ - Thorough peer review \\ - No space constraints or color figure charges \\ - Immediate publication on acceptance \\ - Inclusion in PubMed, CAS, Scopus and Google Scholar \\ - Research which is freely available for redistribution

